TRIBUTE

\section{An academic for the people: A tribute to Evan Weissman}

Jessi Lyons *

Brady Farm
Special issue:

Food as a Tool for Social Change FALK Svracuse $_{\text {Universiyy }}$

Submitted May 17, 2021 / Published online September 16, 2021

Citation: Lyons, J. (2021). An academic for the people: A tribute to Evan

Weissman. Journal of Agriculture, Food Systems, and Community Development,

10(4), 19-20. https://doi.org/10.5304/jafscd.2021.104.018

Copyright (C) 2021 by the Author. Published by the Lyson Center for Civic Agriculture and Food Systems. Open access under CC-BY license.

A cademics have a habit of viewing communities, especially those facing extreme need, as willing 1 subjects to be researched. Places to continually insert field trips and big questions so that students can get degrees and professors can write papers and get tenure. In a city like Syracuse, where we have multiple universities and nationally high levels of negative indicators of well-being, academics pose a quiet and grave threat to the morale of citizens. Being studied, semester after semester, without meaningful change or benefit from those efforts, only feeds civic hopelessness and encourages students to view communities as "other than" themselves, instead of something they are part of.

Evan Weissman was the antithesis of that sort of academic. Maybe not always, but he admitted when he saw his intentions were misplaced. As a researcher, Evan was willing to put himself in authentic relationships with the community. He listened, and was willing to be chided, because he knew there was truth that he hadn't heard yet. To sit at the table with elder gardeners, with farmers and businesspeople, and with people who were superficially completely different than one, requires one to be more than an academic. It requires nerve, patience, a tender heart, and the humility to listen to the wisdom of others more than academic theory. Listening and placing himself and students in reciprocal relationships within the community were part of what made Evan's work so profound.

At the Brady Farm, in Syracuse, Evan would approach me with questions or a possible proposal. Yes, it was rooted in theory, but it was more importantly rooted in years of listening to the community that he immersed himself in. And he always asked how the work he proposed, or student research, could be beneficial to us. Community gardeners had his phone number, and he worked hard to make sure that

* Jessi Lyons, Coordinator, Brady Farm, Syracuse, NY USA; jlyons@bradyfarm.org 
his place in academia translated into something useful for them. Nothing was ever just a paper; it was people and communities that he was attached to. Whether it was looking at a food system, or the washing space on a farm, Evan made sure his work created tangible value.

Two of Evan's students joined us at the farm as interns in different years. They were paid in academic credit, and hopefully walked away with meaningful knowledge and experience. Anyone who mentors an intern knows that it takes work to have one. These interns labored alongside the farm staff, doing all of the hard work required on an urban farm, and yes, we appreciated the labor. With Evan's help, their time wasn't simply checking off a box doing farm labor for credit. They thought critically about the work and the implications of labor costs, food safety standards, and customer preferences on the big picture of urban agriculture as a movement. Similarly, when Evan used our farm as a focal point for his class, the students were required to be immersed in the farm experience. It wasn't enough to visit and write a paper - their effort was required to directly benefit our farm by the end of the semester. We spent time with individual students and groups, on multiple occasions, and walked away with a farm safety plan, a value-added processing plan and toolkit, and interpretive signage.

I'll always appreciate the students he assigned to work with us, and the interns who gave up their summers for class credit. However, my favorite memories will be shoveling compost with Evan and our friends at Syracuse Grows, in all weather, and with little thanks. The annual resource drive to support community gardeners occurs around Earth Day (April 22). In Syracuse, that means it's generally snowing. And in 11 years, we only had one sunny day. Evan always brought an unflinching willingness to be there, to be the one to lend a hand and not leave anyone behind. He knew that some gardeners would forget to show up, and that he'd spend the day shoveling in sleet or snow. Even when we knew the aggravations that could come with the day, he brought warmth and comradery that made the day feel special and bonded us all together, uplifted by good work done together. He always had the biggest smile on those days. 